\title{
The Use of Selective Agar Medium to Increase the Awareness of Handwashing of Students at SD Negeri 57 Banda Aceh, Indonesia
}

\author{
Dewi Yunita ${ }^{1 *}$, Saidatul Wulya ${ }^{2}$, Sri Muliani ${ }^{2}$, Fathurrahman Luthfi ${ }^{2}$, Anggi Pratiwi ${ }^{3}$, \\ Rika Farhana ${ }^{4}$
}

${ }^{1}$ Department of Agricultural Product Technology, ${ }^{2}$ Agricultural Product Technology Study Program, Faculty of Agriculture, Universitas Syiah Kuala, Banda Aceh, Indonesia

${ }^{3}$ Department of Biology Education, Faculty of Teacher Training and Education, Universitas Syiah Kuala, Banda Aceh, Indonesia

${ }^{4}$ Department of Medical Education, Faculty of Medicine, Universitas Syiah Kuala, Banda Aceh, Indonesia

Submitted: June 20 ${ }^{\text {th }}$ 2019; Revised: May 26 ${ }^{\text {th }}$ 2020; Accepted: January $06^{\text {th }} 2021$

\begin{abstract}
Keywords:
Handwashing

Microbes

Student

primary school

Selective agar

media

Abstract Hand is a part of the body that contains lots of microbes. Handwashing is kind of a clean and healthy lifestyle that is aimed to reduce the number of microbes in the hand. The proper handwashing behavior should be begun to be accustomed since in elementary school, but students' awareness is relatively low. This is alleged because they assumed that their hands look clean. In this community engagement activity on how to wash hands properly, hundred students in national primary school SD Negeri 57 Banda Aceh, Indonesia were involved from March until June 2019 and then ten students were chosen as ambassador of handwashing (ducuta). Two selective media agars were used to grow microbes from the hands of the students before and after hand washing. Several programs (secuta, mocuta, bacuta, and kacuta) were also conducted to measure the success of this activity. There was an increase in understanding the proper way of handwashing from $78 \%$ before socialization to $96 \%$ after the socialization. The results based on the handwashing activity book (bacuta) showed that $50 \%$ of the ducuta have begun to get used to washing their hands properly before eating, after going to the toilet, and after playing recommended by $\mathrm{WHO}$.
\end{abstract}

\section{INTRODUCTION}

Hands are parts of the body that are used most in contact with the environment. The spreading of diseases such as diarrhea, gastrointestinal infections, as well as respiratory system infections can easily happen if the hands are not properly washed (Pratami et al., 2013; Lipinwati et al., 2017). Diarrhea has become the mortality cause of 1.8 million toddlers in developing nations (Sumampouw, 2017). According to the data by the World Health Organization (WHO) and the
Department of Health of Indonesia in 2009, each year on average 100,000 children in Indonesia are dead due to diarrhea (Kartika \& Rahmawati, 2017). In Aceh, the prevalence of diarrhea has increased from $7.5 \%$ in 2013 to $8 \%$ in 2018 (Kemenkes RI, 2018). One of the causal factors is the lack of practice of a clean and healthy lifestyle, especially handwashing, in children between the age of 7 to 12 years old.

The fundamental problem that often occurs is the lack of understanding in elementary students on the importance of handwashing, proper methods of

ISSN 2460-9447 (print), ISSN 2541-5883 (online)

*Corresponding author: Dewi Yunita

Department of Agricultural Product Technology, Faculty of Agriculture, Universitas Syiah Kuala, Jalan Tgk. Hasan Krueng Kalee No.3, Darussalam Banda Aceh, Aceh, 23111, Indonesia

Email:dewi_yunita@unsyiah.ac.id 
handwashing, and time of handwashing (after any activity, after going to the bathroom, and before eating). Based on the research conducted in SD Negeri 001 Karimun, it is known that most of the students do not practice Clean and Healthy Lifestyle (PHBS) due to their lack of understanding of PHBS as well as the inadequate facility to wash their hands (Diana et al., 2014). The assumption that hands should only look clean also becomes a major factor in the lack of practice in handwashing in children (Rachmawati \& Triyana, 2008).

The effort to increase the awareness to properly wash hands-on elementary students is important considering the significant impact of a hand that is contaminated with pathogenic bacteria. One of the efforts is to conduct socialization as an actualization of Tri Darma Perguruan Tinggi. This activity was conducted in SD Negeri 57 Banda Aceh on Maret until June of 2019. The school was chosen due to the short distance from Universitas Syiah Kuala, Banda Aceh to the location $( \pm 150 \mathrm{~m})$.

The research by Angga et al. (2015) shows that four main bacterial contaminants could potentially cause diseases if the hands are not properly washed, including Staphylococcus aureus (53.85\%), Staphylococcus epidermidis (34.62\%), Eschericia coli (7.69\%), and Basillus sp. (3.84\%). Therefore, in this activity, the agar used is (a) Baird-Parker Agar (BPA) which specifically targets the bacterium Staphylococcus aureus with a clear black view of the colony with a clear zone, and (b) Mac Conkey Agar (MCA) which specifically targets Enterococcus faecalis with red colony view as well as Staphylococcus aureus with a pale pink colony view (Bridson, 2006).

\section{METHOD}

This activity was conducted in three stages, which are pre-socialization, socialization, and post-socialization. The pre-socialization stage includes all preparations such as scheduling, making the agar media, procurement of equipment, as well as preparation of socialization materials. SD Negeri 57 Banda Aceh has been facilitated with water faucets and a soap dispenser installed near the faucets, enabling the students to immediately wash their hands.

The activities during socialization were conducted by explaining six steps of handwashing as recommended by the World Health Organization, which are (a) spreading the soap on both palms in a rotating manner; (b) rubbing the back of the left hand with the right palm through the dorsum; (c) rubbing the dorsum with the palms touching each other; (d) rubbing the knuckles with the tip of the fingers; (e) rotational rubbing with the left thumb clasped in the right palm and vice versa; and (f) rubbing the right nails and fingertips on the left palm, and vice versa (WHO, 2020). Those materials were delivered to the students through presentation (Figure 1.a) and demonstration (Figure 1.b). The next step is to practice the handwashing technique and stick the surface of the palms to agar media, which are Baird-Parker Agar (BPA) and Mac Conkey Agar (MCA) before and after the students wash their hands. The handwashing activity can be seen in Figure 1.c and the sticking of the palms into agar can be seen in Figure 1.d.
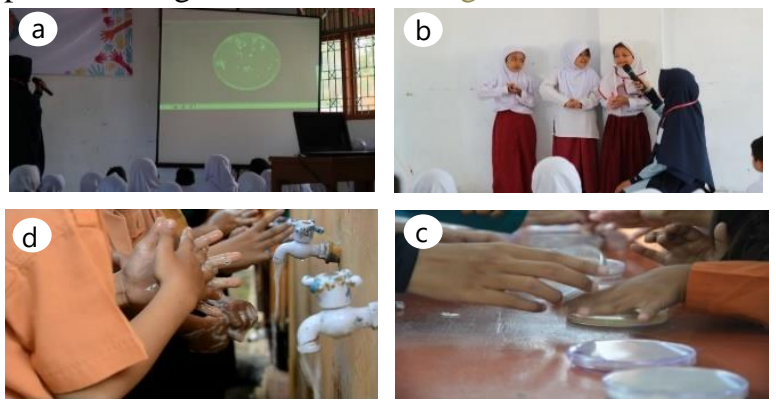

Figure 1. Activities during the socialization: a) Watching the handwashing video; b) Practicing handwashing dance; c) Washing hands with soap; and d) Sticking hands on agar media.

This activities during the socialization involves 100 students. The handwashing module or modul cuci tangan (mocuta; Appendix 1), handwashing activity book or buku aktivitas cuci tangan (bacuta; Appendix 2), and handwashing card or kartu cuci tangan (kacuta; Appendix 3) were designed to enable the elementary students to easily understand and practice the proper way of handwashing. Ten students were then chosen using quota sampling as duta cuci tangan (ducuta; Figure 2), ambassador of handwashing, which acts as promotors and motivators of handwashing for the other students in the school. The criteria include: (a) students from Grade 4 and 5 of SD Negeri 57 Banda Aceh, (b) recommended by the homeroom teacher, (c) willing to follow every step of the activity, and (d) achieved 100 marks on the pre-test. Ducuta teaches the handwashing dance or senam cuci tangan (secuta) every Monday morning (after the morning ceremony) in the schoolyard (Figure 3). The success rate of this socialization was measured through questionnaires (Appendix 4) provided to all the participants before and after they are given the materials.

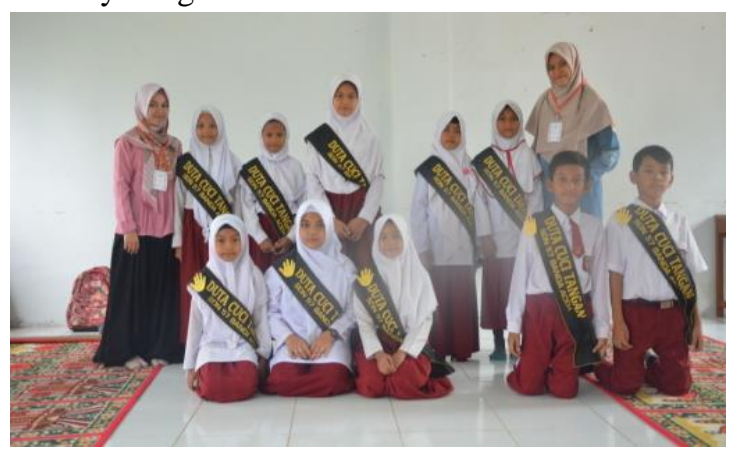

Figure 2. Duta Cuci Tangan in SD N 57 Banda Aceh 


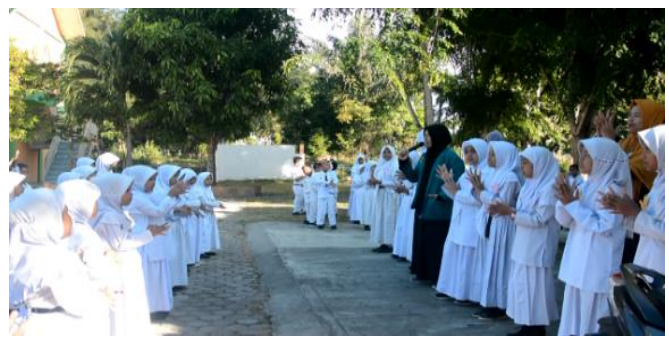

Figure 3. Handwashing dance after Monday morning ceremony

During the post-socialization stage, further evaluation on the continuity of the handwashing activity by the students of SD Negeri 57 Banda Aceh involved their parents and were done through direct supervision in their homes within one month. At this level, the ten ducutas were involved in filling bacuta and their father/mother were involved in answering a questionnaire (Appendix 5).

The validity and reliability of all questionnaire data from the parents were analyzed using the software IBM SPSS Statistics 22. The validity of the questions was known by correlating the question score from the total score using Pearson correlation test. The statements were considered valid if the equated $r$ is equal or more to table $r$ with the significance rate of $5 \%$. A reliability test was done to test the consistency of the measuring instruments, whether it shows a consistent result if the measuring process is repeated. Reliability test was done using Cronbach's alpha method with the limit of 0.60 to determine whether or not a variable is reliable. If the Cronbach's alpha value is bigger than 0.60 , the variable is reliable. However, if the value is less than 0.60 , the variable is not reliable.

\section{RESULT AND DISCUSSION}

\subsection{Description of Respondents' Characteristics}

Hundred students involved at socialization are students
Of Grade 4 and 5 in SD N 57 Banda Aceh. The characteristics of respondents based on their genders showed that the majority of the respondents are female $(80 \%)$. In addition, based on age, $50 \%$ of the respondents are eleven-year-olds, $40 \%$ are ten-yearolds, and $10 \%$ are 12 -year-olds.

\subsection{Questionnaire as A Benchmark for Student's Knowledge and Awareness}

The students' understanding before and after given the socialization was measured with three questionnaires. The first questionnaire (Appendix 4) consisted of six questions that had to be filled by the students. The six questions included the definition of handwashing, the materials used to wash hands, the time of handwashing, as well as the procedure of handwashing in six steps. Their results can be seen in Table 1 . The validity and reliability test showed that all students' knowledge and awareness variables are valid and reliable.

From Table 1, the number of correct answers rose from $78 \%$ before the students were given the material, to $96 \%$ after they were given the materials. This shows that there was an increase in students' knowledge of the proper way of handwashing. This increase hopes to encourage the students to apply the proper way of handwashing in their daily lives.

The second and third questionnaires were given to the parents. The second questionnaire consists of four questions related to their knowledge on handwashing as well as their view towards their children's knowledge on handwashing. The third questionnaire consists of three questions related to the parents' observation of their children's handwashing habit. The results of both questionnaires can be seen in Table 2 and Table 3, respectively. The validity and reliability test shows that all the variables of the parents' responses are valid and reliable.

Table 1. Percentage of students' questionnaire answers $(n=100)$

\begin{tabular}{|c|c|c|c|c|c|c|c|c|}
\hline \multirow[t]{2}{*}{ Question } & \multicolumn{2}{|c|}{$\begin{array}{l}\text { Before } \\
\text { Socialization }\end{array}$} & \multicolumn{2}{|c|}{ After Socialization } & \multirow[t]{2}{*}{$\mathrm{r}_{\text {calculated }}$} & \multirow[t]{2}{*}{$\mathrm{r}_{\text {table }}$} & \multirow[t]{2}{*}{ Cronbach $\alpha$} & \multirow[t]{2}{*}{ Interpretation } \\
\hline & Right & Wrong & Right & Wrong & & & & \\
\hline 1 & $100 \%$ & $0 \%$ & $100 \%$ & $0 \%$ & 0.430 & 0.196 & 0.675 & $\begin{array}{l}\text { Valid and } \\
\text { Reliable }\end{array}$ \\
\hline 2 & $100 \%$ & $0 \%$ & $90 \%$ & $10 \%$ & 0.485 & 0.196 & 0.675 & $\begin{array}{l}\text { Valid and } \\
\text { Reliable }\end{array}$ \\
\hline 3 & $90 \%$ & $10 \%$ & $100 \%$ & $0 \%$ & 0.409 & 0.196 & 0.675 & $\begin{array}{l}\text { Valid and } \\
\text { Reliable }\end{array}$ \\
\hline 4 & $100 \%$ & $0 \%$ & $100 \%$ & $0 \%$ & 0.406 & 0.196 & 0.675 & $\begin{array}{l}\text { Valid and } \\
\text { Reliable }\end{array}$ \\
\hline 5 & $40 \%$ & $60 \%$ & $90 \%$ & $10 \%$ & 0.320 & 0.196 & 0.675 & $\begin{array}{l}\text { Valid and } \\
\text { Reliable }\end{array}$ \\
\hline 6 & $40 \%$ & $60 \%$ & $100 \%$ & $0 \%$ & 0.381 & 0.196 & 0.675 & $\begin{array}{l}\text { Valid and } \\
\text { Reliable }\end{array}$ \\
\hline Average & $78 \%$ & $22 \%$ & $96 \%$ & $4 \%$ & & & & \\
\hline
\end{tabular}


The data in Table 2 explains that all parents know that handwashing is a habit that must be implemented in daily activities for it can reduce the disease prevalence rate. All the parents have observed and concluded that their children know how to properly wash their hands and when they should do so. This shows that the parents support the activity to increase the children's awareness to wash their hands. The result presents the average of $70 \%$ of children who have got used to washing their hands before eating, $80 \%$ have got used to washing their hands after going to the bathroom, and $60 \%$ have got used to washing their hands after playing (Table 3). There are $40 \%$ who have not got used to washing their hands after playing due to the activity, presumably due to such activity is often neglected. Elfiadi (2016) stated that playing can be an exciting and intoxicating activity for the children, thus the act of washing their hands afterward is often overlooked. Most children spent their time watching television and $64 \%$ of them spent their time playing with gadgets daily (Vitariusova et al., 2010).

\section{Table 2. Percentage of parents' response on knowledge on handwashing $(n=10)$}

\begin{tabular}{|c|c|c|c|c|c|c|}
\hline \multirow[b]{2}{*}{ Parents' Knowledge } & \multicolumn{2}{|c|}{ Parents' Responses } & \multirow[b]{2}{*}{$\mathrm{r}_{\text {calculated }}$} & \multirow[b]{2}{*}{$\mathrm{r}_{\text {table }}$} & \multirow[b]{2}{*}{$\begin{array}{c}\text { Cronbach } \\
\alpha\end{array}$} & \multirow[b]{2}{*}{ Interpretation } \\
\hline & Knowing & $\begin{array}{c}\text { Not } \\
\text { Knowing }\end{array}$ & & & & \\
\hline $\begin{array}{l}\text { Parents knowing that } \\
\text { properly washing } \\
\text { one's hand is a form } \\
\text { of a clean and } \\
\text { healthy lifestyle that } \\
\text { should be applied in } \\
\text { daily lifes. }\end{array}$ & $100 \%$ & $0 \%$ & 0.600 & 0.196 & 0.778 & $\begin{array}{l}\text { Valid and } \\
\text { Reliable }\end{array}$ \\
\hline $\begin{array}{l}\text { Parents knowing that } \\
\text { properly } \\
\text { handwashing can } \\
\text { reduce the disease } \\
\text { prevalence rate in } \\
\text { children. }\end{array}$ & $100 \%$ & $0 \%$ & 0.594 & 0.196 & 0.778 & $\begin{array}{l}\text { Valid and } \\
\text { Reliable }\end{array}$ \\
\hline $\begin{array}{l}\text { Children knowing } \\
\text { how to properly } \\
\text { wash their hands. }\end{array}$ & $100 \%$ & $0 \%$ & 0.502 & 0.196 & 0.778 & $\begin{array}{l}\text { Valid and } \\
\text { Reliable }\end{array}$ \\
\hline $\begin{array}{l}\text { Children know } \\
\text { certain times to wash } \\
\text { their hands. }\end{array}$ & $100 \%$ & $0 \%$ & 0.637 & 0.196 & 0.778 & $\begin{array}{l}\text { Valid and } \\
\text { Reliable }\end{array}$ \\
\hline
\end{tabular}

Table 3. Percentage of parents' answer regarding the observation of handwashing activity $(n=10)$

\begin{tabular}{|c|c|c|c|c|c|c|}
\hline \multirow{2}{*}{$\begin{array}{l}\text { Parents' Observation on } \\
\text { Their Children }\end{array}$} & \multicolumn{2}{|c|}{ Parents' Response } & \multirow[b]{2}{*}{$\mathrm{r}_{\text {calculated }}$} & \multirow[b]{2}{*}{$\mathrm{r}_{\text {table }}$} & \multirow{2}{*}{$\begin{array}{c}\text { Cronbach } \\
\alpha\end{array}$} & \multirow[b]{2}{*}{ Interpretation } \\
\hline & Used to & Not Used to & & & & \\
\hline $\begin{array}{l}\text { Children wash their hands } \\
\text { in six steps with soap } \\
\text { before eating }\end{array}$ & $70 \%$ & $30 \%$ & 0.500 & 0.196 & 0.674 & $\begin{array}{l}\text { Valid and } \\
\text { Reliable }\end{array}$ \\
\hline $\begin{array}{l}\text { Children wash their hands } \\
\text { in six steps with soap after } \\
\text { going to the toilet }\end{array}$ & $80 \%$ & $20 \%$ & 0.453 & 0.196 & 0.674 & $\begin{array}{l}\text { Valid and } \\
\text { Reliable }\end{array}$ \\
\hline $\begin{array}{l}\text { Children wash their hands } \\
\text { in six steps with soap after } \\
\text { playing }\end{array}$ & $60 \%$ & $40 \%$ & 0.505 & 0.196 & 0.674 & $\begin{array}{l}\text { Valid and } \\
\text { Reliable }\end{array}$ \\
\hline
\end{tabular}

\subsection{View on the Bacteria in Students' Hands-on Agar Media}

Selective agar media were used to grow the colonies of bacteria as concrete proof for the students that a hand that may look clean can contain many bacteria. The use of agar also gives a view and a mean of comparison of the number of bacteria before and after handwashing. Most of the results show a decrease in the number of the colony after the hands have been washed with soap according to the six steps provided by the WHO.

\subsubsection{Baird-Parker Agar (BPA)}


Baird-Parker Agar is a medium used to isolate the bacterium Staphylococcus aureus. This medium is made from glycine, lithium, and tellurite whose composition has been modified to suppress the growth of other bacteria aside from Staphylococcus aureus. In this medium, the isolated Staphylococcus aureus with good growth may make a black colony with a clear zone that requires a coagulation test (Bridson, 2006). In this activity, Staphylococcus aureus with such characteristics was not found, but a colony with a clear zone but not black color was seen. This anomaly often occurs on the other agar media. This phenomenon was explained by Yunita and Dodd (2018) in their research, in which the media M17 which were supposed to be selective for Lactococcus did not show an isolated result of the bacteria accurately, rogosa agar which is selective for Lactobacillus shows not only the growth of lactobacillus, but also Kochuria, sp. Also, Lactobacillus curvatus only grows on de Man Rogosa Sharpe (MRS) agar.

The colony count in the Baird-Parker Agar (BPA) showed a decrease after washing the hands compared to before washing the hands. The average count of colonies before washing the hands was $3.2 \mathrm{x}$ $10^{1} \mathrm{CFU} / \mathrm{cm} 2$ which decreased as much as $65.6 \%$ to 1.1 $\mathrm{x} 10^{1} \mathrm{CFU} / \mathrm{cm} 2$ after the hand has been washed. The bacterial growth in BPA medium can be seen in Figure 4.
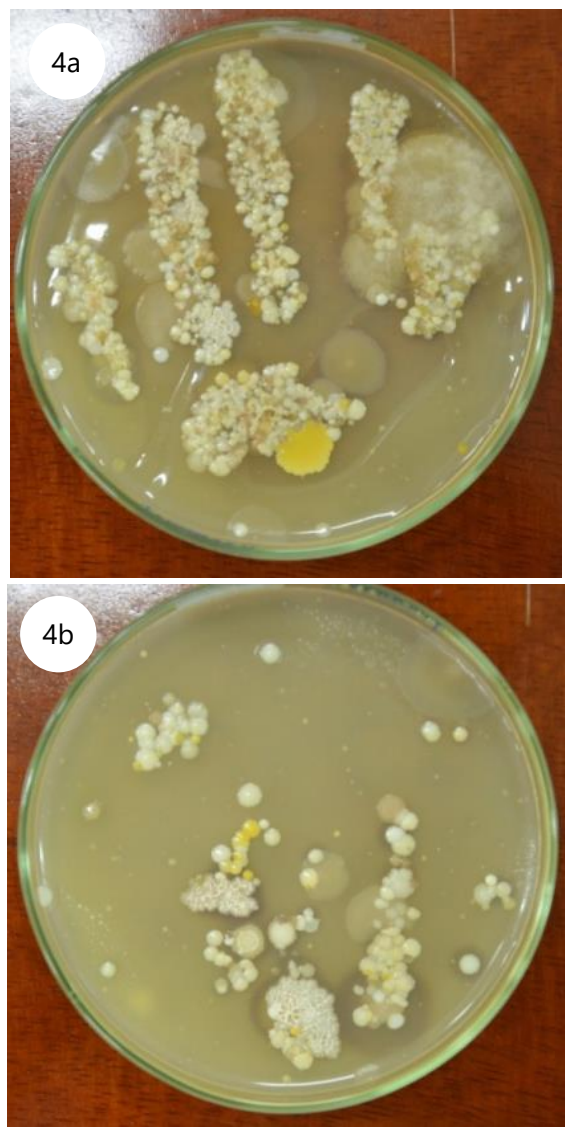

Figure 4. The bacterial growth: a) Before handwashing; and b) After handwashing as shown on BPA medium

\subsubsection{Mac Conkey Agar (MCA)}

Mac Conkey Agar is a medium recommended by WHO that is used to detect, isolate, and enumerate the pathogenic bacteria in the gastrointestinal system. The agar media is not only used for water testing, but also for testing the bacteria in urine, feces, and wounds. This media is specifically used for positive gram coccus bacteria, such as Staphylococcus and Enterococcus (Bridson, 2006). The use of this media is to detect the presence of Eschericia coli with a decent growth characteristic and forms a red colony.

In this activity, the presence of $E$. coli was not detected. The observation shows pink colonies on both hands of the students which were suspected to be Staphylococcus. After the hands have been properly washed, the colony did not show up anymore. The colony count shows a decrease after the hands have been washed compared to before. The average colony count before handwashing was $4.6 \times 10^{\circ} \mathrm{CFU} / \mathrm{cm} 2$ which decreased as much as $78.2 \%$ to $1 \times 10^{\circ} \mathrm{CFU} / \mathrm{cm} 2$ after the hands are properly washed. The growth of bacteria in MCA medium can be seen in Figure 5.
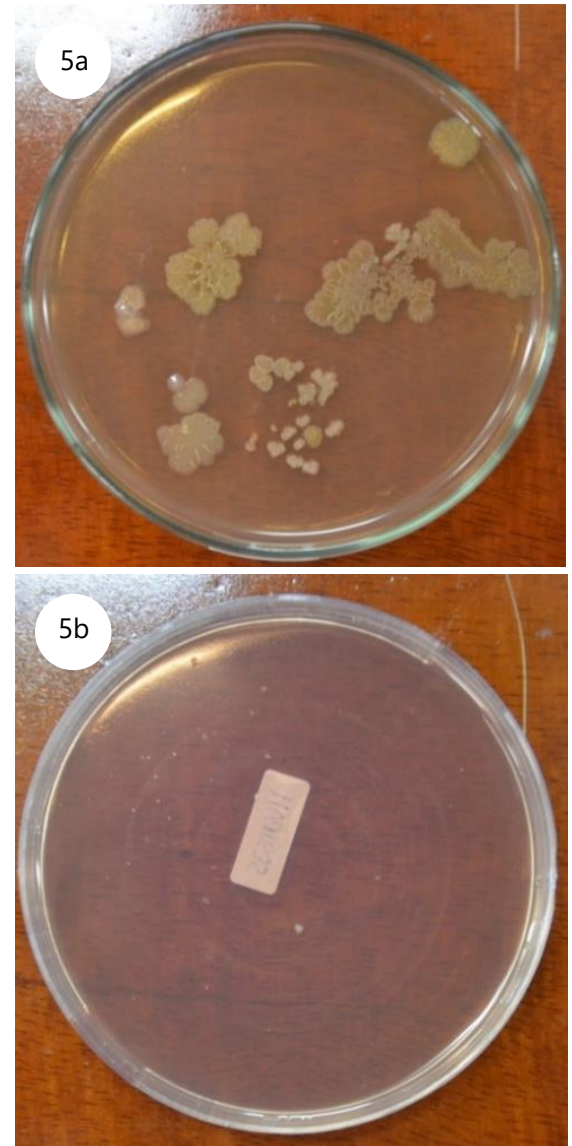

Figure 5. The bacterial growth: a) Before handwashing; and b) After handwashing as shown on MCA medium

\subsection{Evaluation on Ducuta' Handwashing Activity through Handwashing Activity Book}

An evaluation was conducted by asking the ducuta to fill out the Handwashing Activity Book (bacuta) in a month. The bacuta was filled by drawing a check if a 
student has washed hands in the recommended time, such as before eating, after going to the toilet, or after playing. If the students did not wash their hands, they filled the provided column with an "X". The grading of bacuta (Table 4) showed that 5 ducuta have gotten used to washing their hands before eating, after going to the toilet, and after playing.

Table 4. Percentage of ducuta's handwashing activity for 30 days

\begin{tabular}{cccc}
\hline Ducuta & $\begin{array}{c}\text { Before } \\
\text { Eating }\end{array}$ & $\begin{array}{c}\text { After Going to } \\
\text { The Toilet }\end{array}$ & $\begin{array}{c}\text { After } \\
\text { Playing }\end{array}$ \\
\hline 1 & $46 \%$ & $35 \%$ & $50 \%$ \\
2 & $25 \%$ & $32 \%$ & $39 \%$ \\
3 & $30 \%$ & $20 \%$ & $20 \%$ \\
4 & $100 \%$ & $100 \%$ & $100 \%$ \\
5 & $100 \%$ & $89 \%$ & $100 \%$ \\
6 & $100 \%$ & $100 \%$ & $50 \%$ \\
7 & $100 \%$ & $100 \%$ & $100 \%$ \\
8 & $100 \%$ & $100 \%$ & $100 \%$ \\
9 & $100 \%$ & $100 \%$ & $100 \%$ \\
10 & $57 \%$ & $82 \%$ & $57 \%$ \\
\hline
\end{tabular}

\section{CONCLUSION}

Selective agar media has high effectiveness to increase students' awareness of the importance of handwashing in daily life. There was an increase in students' knowledge of the proper way of handwashing after socialization. The parents' questionnaire shows that $70 \%$ of the ducuta have gotten used to washing their hands before eating, $80 \%$ of them have been used to washing their hands after going to the toilet, and $60 \%$ of them have gotten used to washing their hands after playing. However, the grading of bacuta shows that only $50 \%$ of the ducuta have gotten used to washing their hands before eating, after going to the toilet, and after playing. Looking at the microbes under microscope can be conducted in the future socialization. Furthermore, the handwashing activity could reduce the number of microbes grown on BPA (65.6\%) and MCA (78.2\%). Unfortunately, only Staph. aureus and $E$. coli were identified by traditional culturing method. Further research is needed to identify all different colonies morphology grown on both medium by biomolecular method.

\section{ACKNOWLEDGMENT}

This community engagement activity was funded by Ristek Dikti under the Students Creativity Programme (Program Kreativitas Mahasiswa PKM-M) of 2019. The researcher would like to thank SD N 57 Banda Aceh, Lembaga P2KM Universitas Syiah Kuala, Food Microbiology and Agricultural Industry Laboratory in the Faculty of Agriculture, Universitas Syiah Kuala, and Public Health Center, Darussalam, Banda Aceh, Indonesia for their help and cooperation.

\section{REFERENCE}

Angga L., I.M. Darwin P., \& Lia Y.B. (2015). Identifikasi Jenis Bakteri Kontaminan pada Tangan Perawat di Bangsal Penyakit Dalam RSUD Ulin Banjarmasin Periode JuniAgustus 2014. Jurnal Berkala Kedokteran, 11(1), 11-18. DOI http://dx.doi.org/10.20527/jbk.v11i1 .180

Bridson, E.Y. (2006). The Oxoid Manual (9th ed.). England: Oxoid Limited.

Diana, F.M., F. Susanti, \& A. Irfan. (2014). Pelaksanaan Program Perilaku Hidup Bersih dan Sehat (PHBS) di SD Negeri 001 Tanjung Balai Karimun. Jurnal Kesehatan Masyarakat, 8(1), 46-51. DOI: https://doi.org/10.24893/jkma.v8i1.123

Elfiadi. (2016). Bermain dan Permainan bagi Anak Usia Dini. Itqan, 7(1), 51-60.

Kartika, D. \& Rahmawati, D.W.R. (2017). Studi Perilaku Mencuci Tangan terhadap Kepadatan Koloni Bakteri Sebelum dan Setelah Mencuci Tangan pada Mahasiswa. Protobiont, 6(2), $1-7$.

DOI:

http://dx.doi.org/10.26418/protobiont . $\mathrm{v} 6 \mathrm{i} 2.19494$

Lipinwati, Meliana, Siska, \& Permana, O. (2017). Efektivitas Mencuci Tangan dengan Sabun Cuci Tangan Cair Berbahan Aktif Triclocarban pada Mahasiswa Fakultas Kedokteran Universitas Jambi Angkatan 2015. Jambi Medical Journal: Jurnal Kedokteran dan Kesehatan, 5(1), 49-58. DOI: https://doi.org/10.22437/jmj.v5i1.3699

Pratami, H.A., Apriliana, E., \& Rukmono, P. (2013). Identifikasi Mikroorganisme pada Tangan Tenaga Medis dan Paramedis di Unit Perinatologi Rumah Sakit Abdul Moeloek Bandar Lampung. Medical Journal of Lampung University, 2(5), 85-94. ISSN 2337- 3776

Rachmawati, F.J. \& Triyana, S.Y. (2008). Perbandingan angka kuman pada cuci tangan dengan beberapa bahan sebagai standarisasi kerja di laboratorium mikrobiologi Fakultas Kedokteran Universitas Islam Indonesia. Jurnal logika, 5(1), 3-13. ISSN: 1410-2315

Hasil Utama Riskesdas. (2018). Jakarta: Badan Penelitian dan Pengembangan Kesehatan Kementerian Kesehatan, Republik Indonesia.

Sumampouw, O.J. (2017). Diare Balita: Suatu Tinjauan dari Bidang Kesehatan Masyarakat. Yogyakarta: Deepublish. 
Vitariusova, E., K. Babinska, L. Kost'alva, J. Rosinsky, A. Hlavata, Z. Pribilincova, \& K. Babinska Jr, L. Kovacs. (2010). Food Intake, Leisure Time Activities and The Prevalence of Obesity in School Children in Slovakia. Central European Journal of Public Health, 18(4), 192. DOI: 10.21101/cejph.a3607

[WHO] World Health Organization. 2020. Clean hands Protect Against Infection. Retrieved from https://www.who.int/gpsc/clean_hands_prote ction/en/ [Acces in 6 September 2020].

Yunita, D. \& Dodd, C.E.R. (2018). Microbial community dynamics of a blue-veined raw milk cheese from the United Kingdom. $J$. Dairy Sci, 101(6), 4923-4935. DOI: https://doi.org/10.3168/jds.2017-14104 
Appendix 1 Cover and Table of Contents of Handwashing Module (Mocuta)

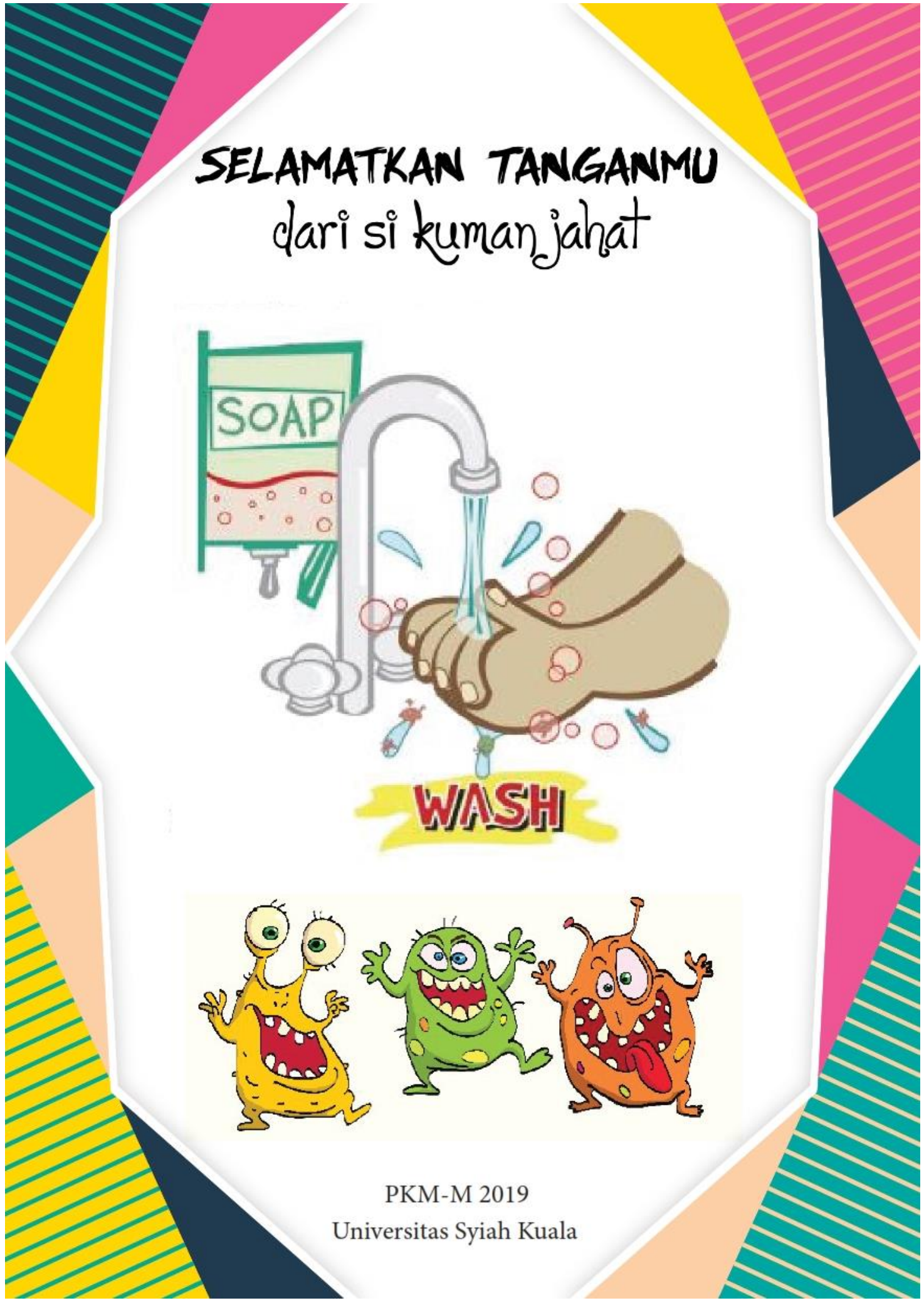




\section{Daftarlsi}

Kata pengantar......

$\mathbf{3}$

Kenalan yuk !!

3

Daftar isi........

4

Kenapa kita harus cuci tangan.

5

Bentuk dan jenis kuman.

7

Kapan saja kita harus mencuci tangan.

6 langkah mencuci tangan........

9

Kalau tangan bersih, kita pun sehat..

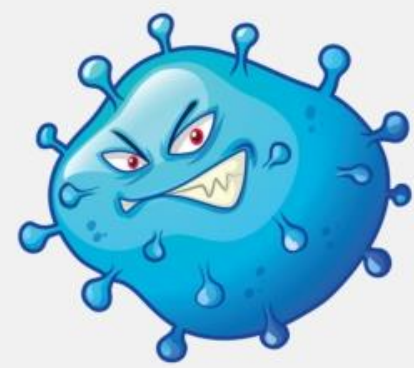




\section{Appendix 2 Handwashing Activity Book (Bacuta)}

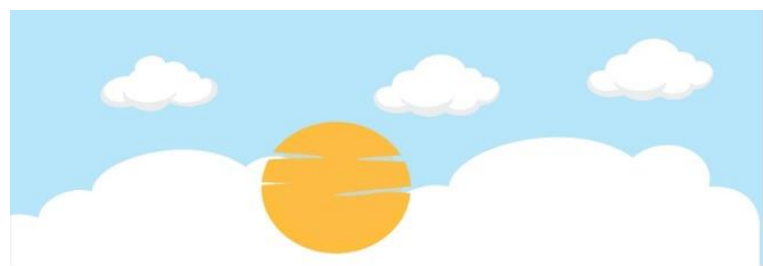

KENAPA Harus
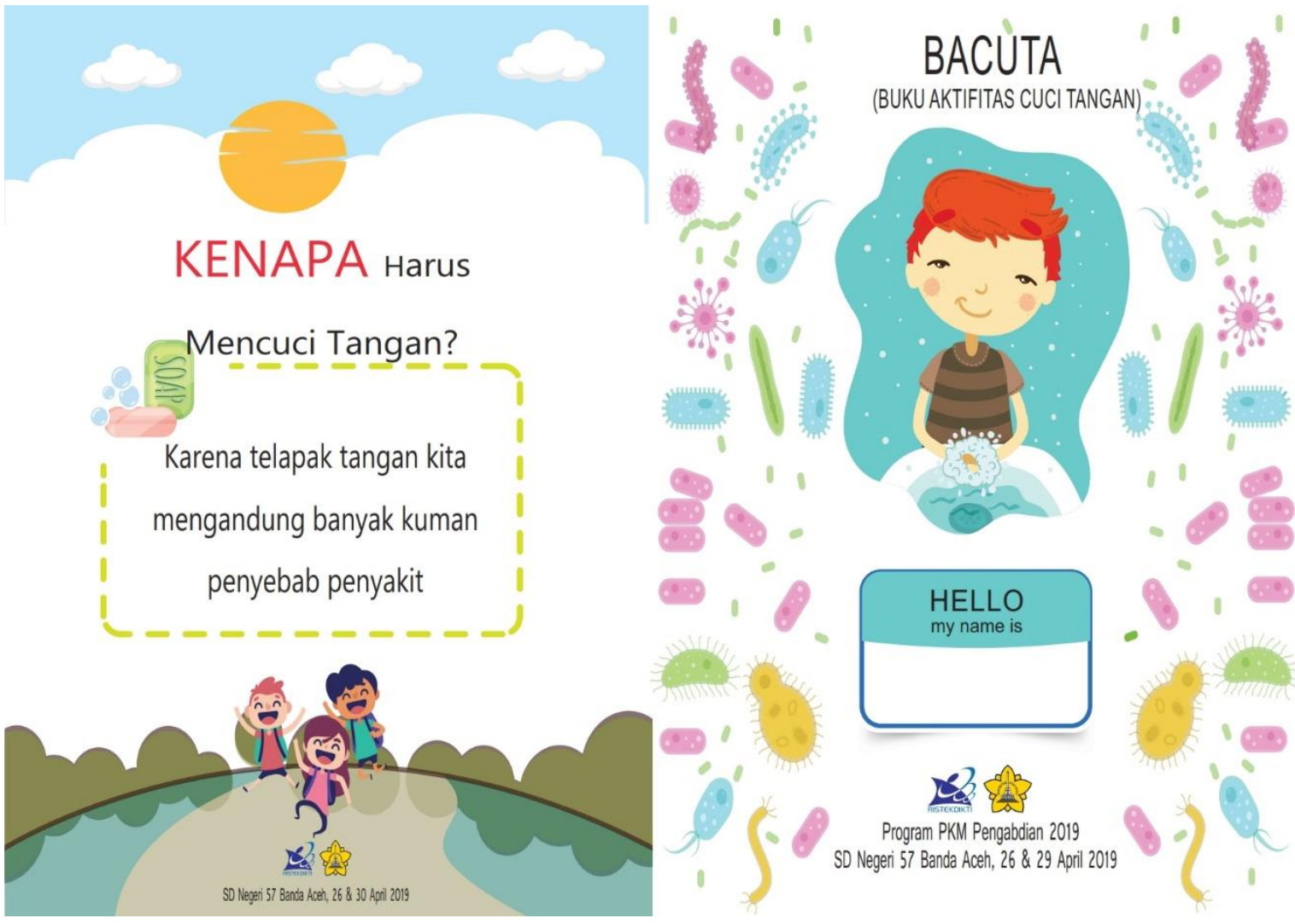
Ket: Apabila sudah mencuci tangan beri tanda contreng $(\sqrt{ })$

\begin{tabular}{|c|c|c|c|c|}
\hline \multicolumn{2}{|c|}{ MEI } & \multicolumn{3}{|c|}{ Cuci Tangan } \\
\hline \multirow[b]{2}{*}{ Minggu } & & $\begin{array}{l}\text { Sebelum } \\
\text { Makan }\end{array}$ & $\begin{array}{l}\text { Setelah } \\
\text { dari WC }\end{array}$ & $\begin{array}{l}\text { Setelah } \\
\text { bermain }\end{array}$ \\
\hline & Tanggal & & & \\
\hline \multirow{7}{*}{1} & 01/05/2019 & & & \\
\hline & $02 / 05 / 2019$ & & & \\
\hline & $03 / 05 / 2019$ & & & \\
\hline & $04 / 05 / 2019$ & & & \\
\hline & 05/05/2019 & & & \\
\hline & 06/05/2019 & & & \\
\hline & $07 / 05 / 2019$ & & & \\
\hline \multirow{7}{*}{ II } & 08/05/2019 & & & \\
\hline & 09/05/2019 & & & \\
\hline & $10 / 05 / 2019$ & & & \\
\hline & $11 / 05 / 2019$ & & & \\
\hline & $12 / 05 / 2019$ & & & \\
\hline & $13 / 05 / 2019$ & & & \\
\hline & $14 / 05 / 2019$ & & & \\
\hline
\end{tabular}

\begin{tabular}{|c|c|c|c|c|}
\hline \multicolumn{2}{|c|}{ MEI } & \multicolumn{3}{c|}{ Cuci Tangan } \\
\hline \multirow{4}{*}{ Minggu } & Tanggal & $\begin{array}{c}\text { Sebelum } \\
\text { Makan }\end{array}$ & $\begin{array}{c}\text { Setelah } \\
\text { dari WC }\end{array}$ & $\begin{array}{c}\text { Setelah } \\
\text { bermain }\end{array}$ \\
\hline \multirow{7}{*}{ III } & $15 / 05 / 2019$ & & & \\
\hline & $16 / 05 / 2019$ & & & \\
\hline & $17 / 05 / 2019$ & & & \\
\hline & $18 / 05 / 2019$ & & & \\
\hline & $19 / 05 / 2019$ & & & \\
\hline & $20 / 05 / 2019$ & & & \\
\hline & $21 / 05 / 2019$ & & & \\
\hline \multirow{4}{*}{ IV } & $22 / 05 / 2019$ & & & \\
\hline & $23 / 05 / 2019$ & & & \\
\hline & $24 / 05 / 2019$ & & & \\
\hline & $26 / 05 / 2019$ & & & \\
\hline & $27 / 05 / 2019$ & & & \\
\hline & $28 / 05 / 2019$ & & & \\
\hline
\end{tabular}




\section{Appendix 3 Handwashing Card (Kacuta)}
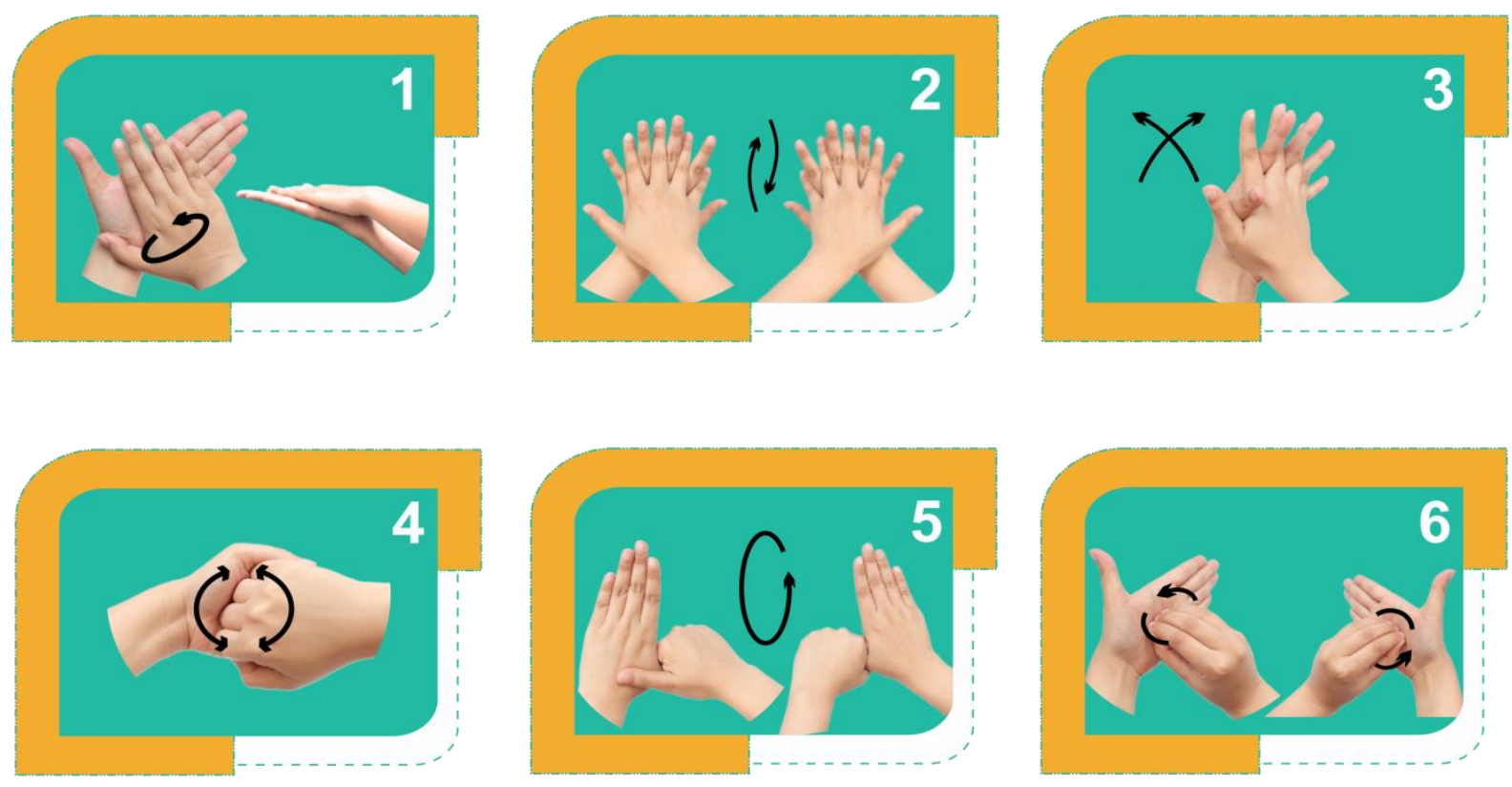
Appendix 4 Questionnaire for Students

$\begin{array}{ll}\text { Nama } & \text { : } \\ \text { Kelas } & \text { : }\end{array}$

\section{SEHAT DIMULAI DARI TANGAN}

Berilah tanda centang $(\sqrt{ })$ pada jawaban yang dianggap paling tepat.

1. Supaya tidak mudah terserang penyakit kita harus membiasakan mencuci?
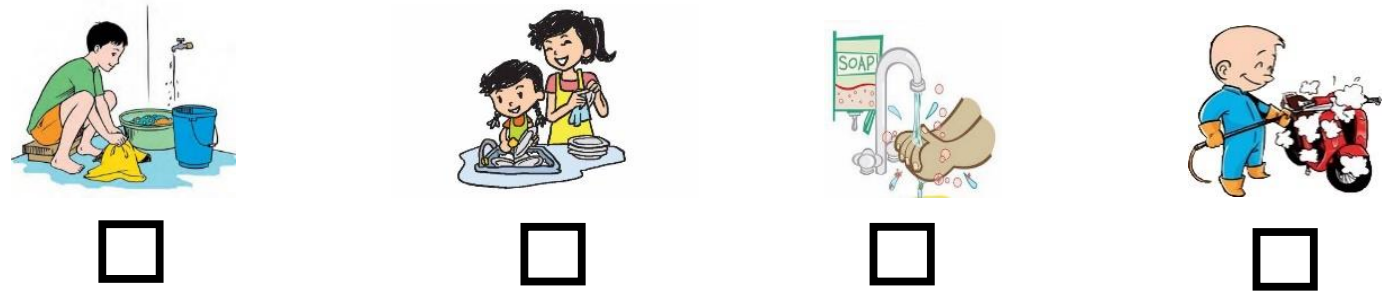

2. Tangan kita adalah bagian tubuh yang paling banyak digunakan sehari- hari. Oleh karena itu, tangan sering menjadi perantara penularan penyakit. Maka kita harus sering mencuci tangan menggunakan?
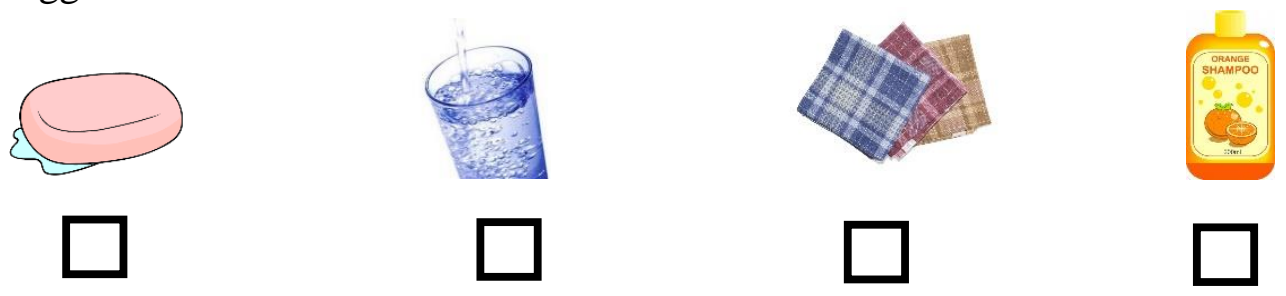

3. Kita harus mencuci tangan setelah keluar dari?
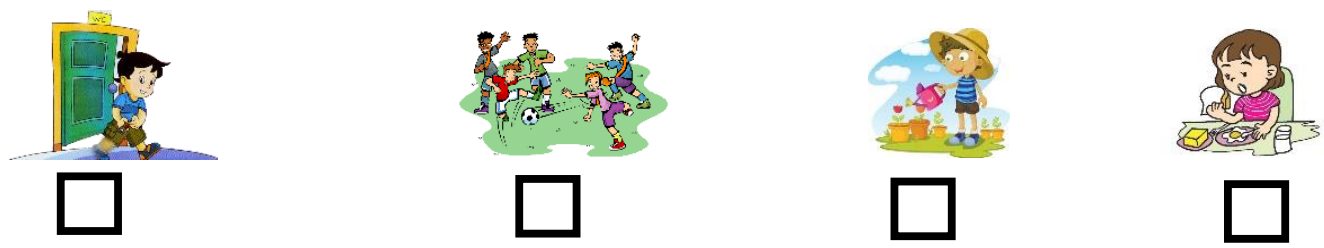

4. Kita harus mencuci tangan sebelum?
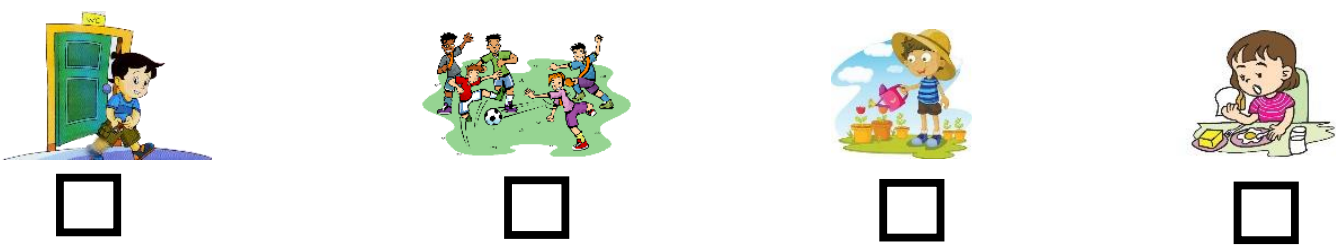

5. Kita harus mencuci tangan setelah? 

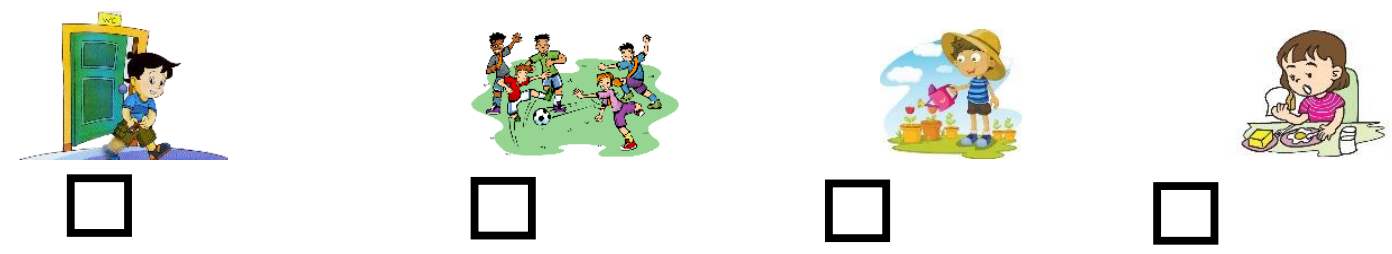

6. Ada 6 langkah mencuci tangan dengan benar. Berilah nomor pada setiap langkah mencuci tangan di bawah ini dengan benar dan tepat!

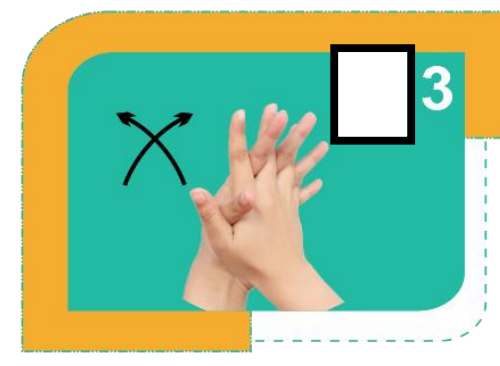

Gosok sela-sela jari dengan telapak tangan saling menempel

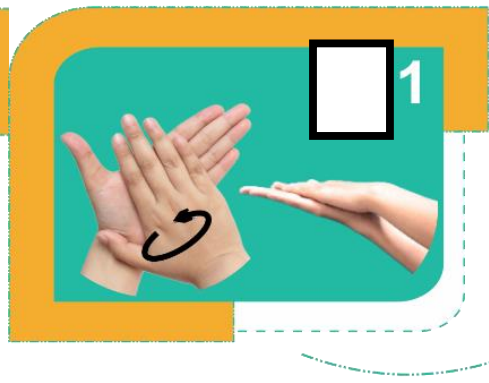

Ratakan sabun pada kedua telapak tangan dengan gerakan memutar

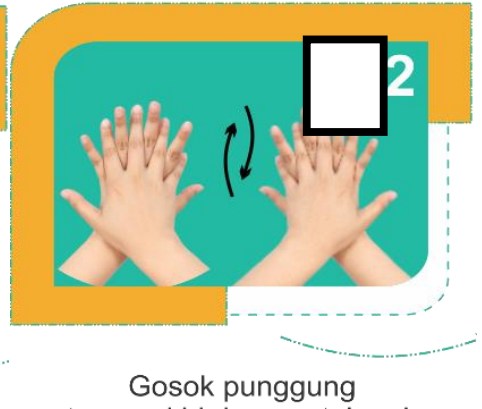

tangan kiri dengan telapak tangan kanan, sampai sela-sela jari dan lakukan sebaliknya.

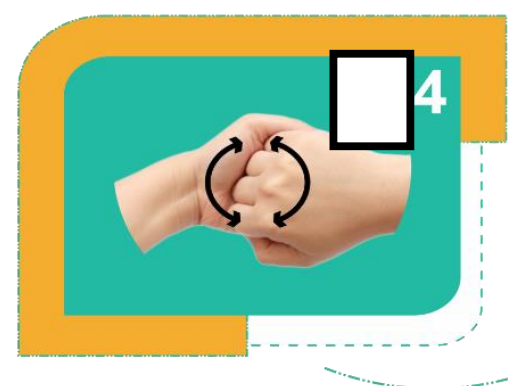

Gosok buku-buku jari dengan kunci ujung jari

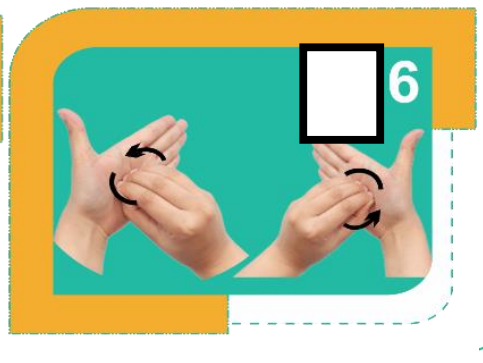

Gosok kuku dan ujung jari kanan pada telapak tangan kiri, lakukan sebaliknya

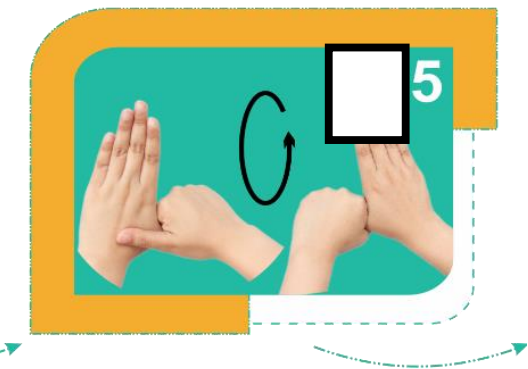

Gosok jempol tangan kiri dalam genggaman dengan gerakan memutar dan keluar, lakukan sebaliknya 


\section{Appendix 5 Questionnaire for Parents}

\section{Identitas responden}

Nama Orang Tua/Wali :

Nama Anak

Kelas

No. HP orang tua

Alamat

A. Penngetahuan responden tentang kegiatan mencuci tangan

Berilah tanda centang $(\sqrt{ })$ pada kolom di bawah.

\begin{tabular}{|c|l|c|c|}
\hline No. & \multicolumn{1}{|c|}{ Pernyataan } & Tahu & $\begin{array}{r}\text { Tidak } \\
\text { Tahu }\end{array}$ \\
\hline 1. & $\begin{array}{l}\text { Mencuci tangan dengan benar adalah bentuk } \\
\text { perilaku hidup bersih dan sehat yang seharusnya } \\
\text { diterapkan dalam kehidupan sehari-hari }\end{array}$ & \\
\hline 2. & $\begin{array}{l}\text { Mencuci tangan dengan benar dapat menurunkan } \\
\text { angka kejadian penyakit pada anak (contoh: } \\
\text { diare) }\end{array}$ & $\begin{array}{l}\text { Anak Bapak/Ibu mengetahui cara mencuci } \\
\text { tangan yang benar }\end{array}$ & $\begin{array}{l}\text { Anak Bapak/Ibu mengetahui waktu tertentu } \\
\text { kapan harus mencuci tangan }\end{array}$ \\
\hline 3. & & \\
\hline
\end{tabular}

\section{B. Evaluasi kebiasaan mencuci tangan}

Berilah tanda centang $(\sqrt{ })$ pada kolom di bawah berdasarkan kartu kontrol.

\begin{tabular}{|c|c|c|c|}
\hline No. & Pernyataan & Biasa & $\begin{array}{l}\text { Tidak } \\
\text { Biasa }\end{array}$ \\
\hline 1. & $\begin{array}{l}\text { Anak Bapak/Ibu mencuci tangan } 6 \text { langkah } \\
\text { dengan sabun sebelum makan }\end{array}$ & & \\
\hline 2. & $\begin{array}{l}\text { Anak Bapak/Ibu mencuci tangan } 6 \text { langkah } \\
\text { dengan sabun setelah dari toilet }\end{array}$ & & \\
\hline 3. & $\begin{array}{l}\text { Anak Bapak/Ibu mencuci tangan } 6 \text { langkah } \\
\text { dengan sabun setelah bermain }\end{array}$ & & \\
\hline
\end{tabular}

